\title{
Analisis Kinerja Saham Individual pada Industri Farmasi di Bursa Efek Indonesia tahun 2016
}

\author{
M. Nazori Majid, Melisa Oktavina \\ Fakultas Ekonomi dan Bisnis Islam UIN Sulthan Thaha Saifuddin Jambi \\ email: nazori.muhammad@yahoo.com
}

\begin{abstract}
Abstrak: Penelitian ini bertujuan untuk mengetahui kinerja saham individual industri farmasi yang terdaftar di Bursa Efek Indonesia (BEI) tahun 2016. Metode analisis yang digunakan adalah Geometric Mean Return, Standar Deviasi, Sharpe Indeks Performance dan Treynor Indeks Performance. Hasil penelitian ini menunjukkan tingkat return saham industri farmasi dari yang tertinggi yang dicapai oleh Indofarma Tbk (1.333\%) sampai return terendah pada Merck Sharp Dohme Pharma Tbk $(0.000 \%)$. Tingkat resiko (standar deviasi) tertinggi ada pada tiga perusahaan yaitu Indofarma Tbk, Kimia Farma Tbk dan Pyridam Pharma Tbk. Perusahaan dengan kinerja terbaik pada penelitian ini menurut pengukur Sharpe adalah Indofarma Tbk, sedangkan menurut pengukur Treynor kinerja terbaik dicapai oleh Kimia Farma Tbk. Perbedaan peringkat kinerja ini menunjukkan jika saham-saham dalam industri farmasi belum termasuk potofolio yang optimal.

Kata-kata kunci: kinerja saham, return, sharpe indeks performance, treynor mance.
\end{abstract}

\section{Pendahuluan}

Kinerja saham merupakan bagian dari penilaian kinerja perusahaan dan salah satu indikator keberhasilan perusahaan. Jika kinerja saham suatu perusahaan selalu mengalami kenaikan maka investor atau calon investor akan menilai perusahaan berhasil dalam mengelola usahanya. Menurut Henry, kinerja saham yang baik menunjukkan kinerja perusahaan yang baik pula. Nilai saham bisa menjadi indeks yang tepat untuk mengukur tingkat efektifitas perusahaan. Dalam penelitian yang dilakukan oleh Yuliandiny Ekawati juga menyatakan bahwa kinerja saham merupakan cerminan dari nilai perusahaan.

Kinerja sebuah perusahaan dapat dinilai dari return saham yang diperolehnya dalam suatu periode tertentu. Selain menilai kinerja perusahaan, return saham juga dapat digunakan oleh para investor untuk menilai kinerja saham sebelum akhirnya menetapkan pilihan untuk membeli saham atau tidak. Analisis kinerja indeks harga saham dapat dilakukan sebagai acuan dalam melakukan investasi.

Return saham merupakan salah satu standar tolak ukur keberhasilan kinerja saham pada sebuah perusahaan. Pada setiap pengambilan keputusan investasi, investor akan menghadapi ketidakpastian terhadap return yang akan diperoleh. Ketidakpastian ini lah yang disebut sebagai risiko investasi. Namun risiko dan return memiliki hubungan yang positif, semakin besar risiko suatu sekuritas maka semakin besar return yang diharapkan. Dan sebaliknya, yaitu semakin kecil risiko suatu sekuritas maka return yang diharapkan juga lebih kecil. Menurut Benjamin Graham, resiko tidak terpisahkan dari keuntungan yang ditawarkannya, dan bahwa resiko berbanding keuntungan tersebut harus dimasukkan ke dalam kalkulasi seorang investor. 
Selanjutnya, persoalan yang tidak kalah pentingnya terkait dengan kebolehan investasi adalah mengenai tindakan spekulasi terhadap risiko (gharar). Dalam bahasa literature manajemen keuangan, risiko yang tidak dapat diperkirakan sebelumnya (unexpected risk) disebut sebagai ketidakpastian. Jenis risiko inilah yang dimaksudkan sebagai gharar. Sebab transaksi dikatakan gharar ketika risiko yang bakal terjadi tidak dapat diprediksi. Sedangkan risiko dalam pasar investasi adalah jenis risiko yang dapat diprediksi. Dengan analisis terhadap probabilitas risiko dan expected return, maka seorang investor dapat melakukan prediksi bisnisnya.

Industri farmasi merupakan bagian dari sektor industri produk konsumsi (consumer goods) yang merupakan sektor dengan kapitalisasi pasar kedua terbesar di Indonesia setelah sektor keuangan. Sektor ini relatif stabil dari fluktuasi ekonomi karena tidak mungkin dikurangi dari anggaran belanja masyarakat, apapun kondisi keuangan masyarakat. Saham kelompok consumer goods merupakan saham non-cyclical, artinya selalu dibutuhkan apapun kondisi ekonomi saat itu sehingga permintaan akan produk ini relatif konstan berapapun harganya.

Perusahaan farmasi atau perusahaan obat-obatan adalah perusahaan bisnis komersial yang fokus dalam meneliti, mengembangkan dan mendistribusikan obat, terutama dalam hal kesehatan. Industri farmasi pertama kali bergabung di Bursa Efek Indonesia pada tahun 1981. Perusahaan farmasi pertama yang memperoleh pernyataan efektif dari Bapepam-LK untuk melakukan penawaaran umum perdana saham adalah Merck Indonesia Tbk pada tanggal 23 Juni 1981, yang kemudian saham-saham tersebut di catatkan di BEI pada tanggal 23 Juli 1981. Sampai akhir tahun 2016 ada 10 perusahaan farmasi yang listing BEI. Selain itu ada pula perusahaan farmasi yang hingga saat ini belum terdafftar di BEI. Berikut daftar perusahaan farmasi yang listing di BEI dan beberapa perusahaan yang belum terdaftar.

Tabel 1 Daftar Perusahaan Farmasi di Indonesia

\begin{tabular}{|l|l|}
\hline Terdaftar Di BEI & \multicolumn{1}{|c|}{ Belum Terdaftar Di BEI } \\
\hline Darya Varia Laboratoria Tbk & PT. Novartis Biochemie \\
\hline Indofarma (Persero) Tbk & PT. Boehringer Ingelheim \\
\hline Kimia Farma (Persero) Tbk & PT. Prima Hexal \\
\hline Kalbe Farma Tbk & PT. Transfarma Medica Indah \\
\hline Merck Indonesia Tbk & PT. Medifarma Laboratories \\
\hline Pyridam Farma Tbk & PT. Marin Liza Pharma \\
\hline Merck Sharp Dohme Pharma Tbk & Bristol Myers Squibb Indonesia \\
\hline Industri Jamu \& Farmasi Sido Muncul Tbk & PT. Insan Idofarma \\
\hline Taisho Pharmaceutical Indonesia Tbk & PT. Medifarma Laboratories \\
\hline Tempo Scan Pacific Tbk & PT. Mahakam Beta Pharma \\
\hline
\end{tabular}


Menurut Clarkson industri farmasi merupakan industri ke-4 yang paling menguntungkan setelah software, perminyakan dan makanan. Dalam penelitian yang dilakukan Ahmad Diasworo juga mengatakan bahwa saham-saham farmasi dapat dipilih sebagai alternatif investasi jangka panjang. Berikut pergerakan saham sektor farmasi periode Januari 2016 - Desember 2016.

Gambar 1 Grafik Pergerakan Harga Saham Sektor Farmasi.

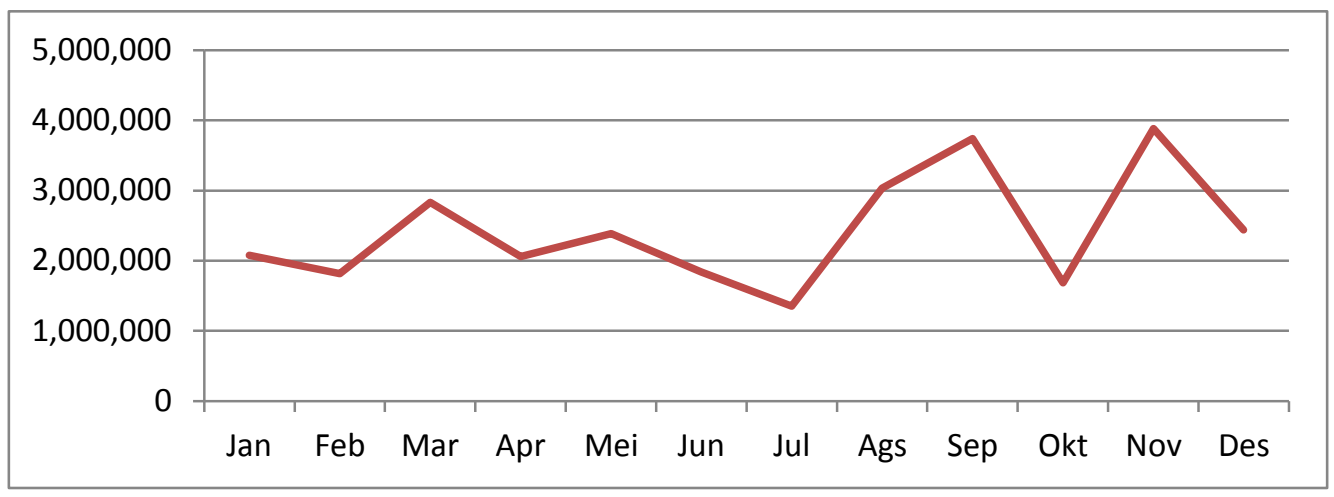

Sumber: www.idx.co.id (data diolah)

Indonesia memiliki tingkat pertumbuhan yang relatif tinggi dan pasar yang besar. Sebagai Negara keempat paling padat penduduknya di dunia dengan perekonomian yang tumbuh pesat, Indonesia berubah menjadi pasar yang penting untuk obat-obatan. Badan Koordinasi Penanaman Modal mencatat nilai investasi untuk industri farmasi dalam kurun waktu sekitar lima tahun hingga 2016, baru sebesar Rp 8,9 triliun. Yang artinya investasi di industri farmasi tidak meningkat pesat. Tidak sesuai jika dilihat dari jumlah penduduk Indonesia yang setiap tahunnya terus mengalami pertumbuhan. Deputi Bidang Pengendalian Pelaksanaan Penanaman Modal BKPM Azhar Lubis mengatakan, BKPM sebagai lembaga yang berwenang mempromosikan investasi telah melakukan tugasnya untuk mempromosikan sektor farmasi. Namun, kenyataannya banyak yang tidak berminat. Padahal, Industri farmasi dinilai sangat berpotensi untuk investor melakukan investasi karena saham yang ada dalam industri farmasi adalah bentuk saham defensive (saham yang mahal atau harga produk yang akan tetap dibeli masyarakat).

Pada tahun 2016 ini jumlah industri farmasi di Indonesia baru mencapai 214 perusahaan. Di tahun 2014, baru ada 192 industri farmasi. Sedangakan pada 2015 naik menjadi 211 industri farmasi. Dan hanya terjadi 3 penambahan di 2016. Seharusnya ada ribuan perusahaan farmasi karena rakyat Indonesia mencapai ratusan juta. Kurangnya minat investor terhadap saham industri farmasi tentunya menimbulkan pertanyaan terkait dengan kinerja saham. Hal ini juga menimbulkan adanya gap antara teori dan hasil riset terhadap fenomena yang ada. Oleh karena itu perlu dilakukan penilaian terhadap masing-masing perusahaan sehingga dapat mengetahui kinerja dari saham perusahaan tersebut. 
Permasalahan yang dapat diurai sebagai berikut: Bagaimana kinerja sahamsaham individual pada industri farmasi yang terdaftar pada Bursa Efek Indonesia periode Januari 2016 - Desember 2016? Bagaimana peringkat kinerja sahamsaham individual pada industri farmasi yang terdaftar di Bursa Efek Indonesia periode Januari 2016 - Desember 2016?

\section{Geometric Mean Return Saham}

Geometrik Mean Return digunakan untuk menghitung rata-rata pertumbuhan harga saham. Perhitungan rata-rata pertumbuhan saham menggunakan rumus sebagai berikut:

$R G=\left[\left(1+R_{1}\right)\left(1+R_{2}\right) \ldots\left(1+R_{n}\right)\right]^{1 / n}-1$ Dengan hasil perhitungan sebagai berikut:

Tabel 2 Rata-rata Pertumbuhan Saham Bulanan tahun 216

\begin{tabular}{|l|l|l|l|l|l|l|l|l|l|l|}
\hline \multirow{2}{*}{ Bln } & \multicolumn{2}{|l}{ Perusahaan } \\
\cline { 2 - 11 } & DVLA & INAF & KAEF & KLBF & MERK & PYFA & SCPI & SIDO & SQBI & TSPC \\
\hline \multirow{2}{*}{ Jan } & -0.00041 & 0.02441 & 0.01118 & 0.00222 & 0.00116 & 0.00048 & 0.0000 & -0.00453 & -0.00142 & 0.00045 \\
\hline Feb & -0.00250 & 0.00916 & -0.00145 & -0.00179 & -0.00093 & -0.00096 & 0.0000 & 0.00104 & 0.00072 & 0.00030 \\
\hline Mar & 0.00145 & 0.01176 & 0.00900 & 0.00646 & 0.00144 & -0.00397 & 0.0000 & -0.00345 & -0.00206 & 0.00489 \\
\hline Apr & 0.01382 & 0.02778 & -0.00726 & -0.00327 & -0.00054 & 0.00327 & 0.0000 & -0.00092 & -0.00009 & -0.00205 \\
\hline Mei & 0.00000 & 0.01105 & -0.00066 & 0.00343 & 0.00316 & 0.00000 & 0.0000 & -0.00254 & -0.00140 & -0.00163 \\
\hline
\end{tabular}

Dapat dilihat bahwa awal tahun 2016 beberapa saham mengalami fluktuasi yang cukup besar, dengan berada pada kisaran minimal -0.01013 dan kisaran maksimal pada 0.04204. Pertumbuhan saham paling tinggi di capai oleh saham Kimia Farma Tbk (KAEF) pada bulan Agustus dengan pertumbuhan sebesar 0.04204 , begitu pula dengan pertumbuhan minimal saham pada angka -0.01013 yang juga terjadi pada saham Kimia Farma Tbk. Saham Indofarma Tbk juga mengalami pertumbuhan yang cukup tinggi jika disbanding saham lainnya, bahkan pergerakannya cenderung lebih stabil jika dibandingkan dengan Kimia Farma Tbk yang mengalami perubahan drastis di bulan-bulan tertentu. Sedangkan delapan saham lainnya di industri farmasi yang terdaftar di Bursa Efek Indonesia memiliki tingkat pertumbuhan yang hampir sama selama periode Januari 2016 - Mei 2016. Untuk rata-rata pertumbuhan saham farmasi dalam setahun dapat dilihat di tabel berikut: 
Tabel 3 Pertumbuhan Saham Farmasi Tahun 2016

\begin{tabular}{|l|l|l|}
\hline Perusahaan & $\begin{array}{l}\text { Geometrik Mean } \\
\text { Return }\end{array}$ & Persentase \\
\hline DVLA & 0.00182 & $0.182 \%$ \\
\hline INAF & 0.01333 & $1.333 \%$ \\
\hline KAEF & 0.00389 & $0.389 \%$ \\
\hline KLBF & 0.00061 & $0.061 \%$ \\
\hline MERK & 0.00096 & $0.096 \%$ \\
\hline PYFA & 0.00248 & $0.248 \%$ \\
\hline SCPI & 0.00000 & $0.000 \%$ \\
\hline SIDO & -0.00068 & $0.068 \%$ \\
\hline SQBI & 0.00077 & $0.077 \%$ \\
\hline TSPC & 0.00065 & $0.065 \%$ \\
\hline
\end{tabular}

Dari tabel di atas terlihat bahwa pada tahun 2016 perusahaan farmasi yang memiliki rata-rata tingkat pertumbuhan saham tertinggi adalah perusahaan Indofarma Tbk (INAF) sebesar $1.333 \%$. Dan rata-rata pertumbuhan terendah dialami oleh perusahaan Merck Sharp Dohme Pharma Tbk (SCPI) sebesar 0.000\%, yang artinya tidak ada peningkatan sama sekali.

\section{Standar Deviasi Perusahaan Farmasi}

Standar Deviasi digunakan untuk menghitung resiko. Perhitungan resiko individual menggunakan rumus berikut:

$$
\sigma=\sqrt{\sum_{\mathrm{i}-1}^{\mathrm{n}}\left[\mathrm{R}_{\mathrm{i}}-\mathrm{E}\left(\mathrm{R}_{\mathrm{i}}\right)\right]^{2} \mathrm{pr}_{\mathrm{i}}}
$$

Dengan hasil perhitungan sebagaimana tabel berikut: 
Tabel 4 Standar Deviasi Perusahaan Farmasi Tahun 2016

\begin{tabular}{|c|c|c|c|c|c|c|c|c|c|c|}
\hline \multirow{2}{*}{ Bln } & \multicolumn{10}{|c|}{ Perusahaan } \\
\hline & DVLA & INAF & KAEF & KLBF & MERK & PYFA & SCPI & SIDO & SQBI & TSPC \\
\hline Jan & 0.01606 & 0.09453 & 0.04461 & 0.03233 & 0.01458 & 0.03523 & 0.00000 & 0.01507 & 0.02634 & 0.01942 \\
\hline Feb & 0.02465 & 0.04682 & 0.01991 & 0.01808 & 0.00752 & 0.00799 & 0.00000 & 0.01076 & 0.00314 & 0.00744 \\
\hline Mar & 0.00720 & 0.02764 & 0.02478 & 0.02610 & 0.01644 & 0.03747 & 0.00000 & 0.00906 & 0.00905 & 0.01727 \\
\hline Apr & 0.05140 & 0.04642 & 0.02787 & 0.01608 & 0.01364 & 0.01363 & 0.00000 & 0.00498 & 0.00035 & 0.02004 \\
\hline Mei & 0.02401 & 0.04704 & 0.01768 & 0.01502 & 0.00946 & 0.01590 & 0.00000 & 0.01652 & 0.00418 & 0.01118 \\
\hline Jun & 0.02747 & 0.05096 & 0.02567 & 0.01826 & 0.01645 & 0.02400 & 0.00000 & 0.01257 & 0.00409 & 0.01373 \\
\hline Jul & 0.02132 & 0.03614 & 0.01674 & 0.02317 & 0.01420 & 0.02918 & 0.00000 & 0.03284 & 0.00000 & 0.02232 \\
\hline Ags & 0.03164 & 0.03761 & 0.07308 & 0.01715 & 0.01454 & 0.07195 & 0.00000 & 0.02509 & 0.04164 & 0.03033 \\
\hline Sep & 0.01349 & 0.06546 & 0.06872 & 0.01960 & 0.02058 & 0.03098 & 0.00000 & 0.02347 & 0.00014 & 0.02445 \\
\hline Okt & 0.01961 & 0.03124 & 0.01848 & 0.00746 & 0.01051 & 0.02169 & 0.00000 & 0.02120 & 0.00000 & 0.01522 \\
\hline Nov & 0.01397 & 0.04611 & 0.06477 & 0.02560 & 0.00957 & 0.08423 & 0.00000 & 0.01962 & 0.00000 & 0.01546 \\
\hline Des & 0.03199 & 0.05547 & 0.03459 & 0.02149 & 0.00985 & 0.01842 & 0.00000 & 0.01703 & 0.00000 & 0.01009 \\
\hline
\end{tabular}

Ada tiga perusahaan yang memiliki standar deviasi yang cukup tinggi dibanding perusahaan lainnya. Yaitu Indofarma Tbk (INAF), Pyridam Pharma Tbk (PYFA), dan Kimia Farma. Pada ketiga perusahaan tersebut memiliki tingkat standar deviasi yang jauh lebih tinggi dibanding perusahaan lainnya. Secara keseluruhan awal tahun 2016 Indofarma Tbk (INAF) merupakan perusahaan dengan rata-rata tingkat standar deviasi tertinggi dibanding perusahaan lainnya, dan Taisho Pharmautical Indonesia tbk (TSPC) merupakan perusahaan dengan rata-rata standar deviasi terendah. 


\section{Sharpe Index Performance dan Treynor Index Performance}

Nilai Sharpe Index Performance menunjukkan kinerja dari portofolio. Semakin besar nilainya, maka semakin baik pula kinerja portofolionya. Perhitungan Sharpe Index Performance menggunakan rumus berikut:

$$
R V A R=\frac{\overline{T R}_{P}-\bar{R}_{B R}}{\sigma_{P}}
$$

Tabel di atas memperlihatkan bahwa indeks Sharpe yang paling tinggi ada pada angka $27.383 \%$ yang dicapai oleh perusahaan Indofarma Tbk. Hampir seluruh perusahaan farmasi di Bursa Efek Indonesia memiliki kinerja Sharpe / RVAR yang positif, yang menandakan kinerja yang cukup baik dari sektor tersebut. Kecuali pada perusahaan Sido Muncul Tbk (SIDO) yang menunjukkan kinerja negatif dan Merck Sharp Dohme Pharma Tbk (SCPI) yang tidak menunjukkan kinerja apa-apa selama tahun 2016.

Nilai Treynor Index Performance menunjukkan kinerja portofolio. Semakin besar nilai Treynor atau RVOL maka semakin baik pula kinerjanya. Perhitungan kinerja Treynor dapat dilakukan dengan menggunakan rumus berikut:

$\mathrm{RVOL}=\frac{\overline{T R}_{P}-R_{B R}}{\beta_{P}}$

Kinerja Treynor selama tahun 2016. yang berada pada kisaran maksimal 0.03073 dan kisaran minimal -0.36555. Kinerja Treynor yang tertinggi dicapai oleh perusahaan Kimia Farma. Pada perhitungan kinerja Treynor tahun 2016 hampir sebagian perusahaan sektor farmasi yang terdaftar di Bursa Efek Indonesia memiliki nilai negatif, yang artinya kinerja Treynor pada sektor farmasi selama periode tersebut belum terlalu baik.

\section{Penutup}

Setelah melakukan analisis terhadap kinerja saham individual pada industri farmasi yang terdaftar di Bursa Efek Indonesia periode awal 2016 yang telah di jelaskan pada bab sebelumnya, maka dapat ditarik kesimpulan sebagai berikut: Pertama, Kinerja saham individual industri farmasi selama awal 2016 tidak bisa sepenuhnya dikatakan baik. Tercatat hanya saham Indofarma Tbk yang rata-rata tingkat pengembalian returnnya selalu posisitf selama tahun 2016. Sedangkat Sembilan saham lainnya cenderung bergerak pada tingkat yang sama dan beberapa kali mengalami kenaikan ataupun penurunan drastis selama periode tersebut. Kedua, Peringkat kinerja saham industri farmasi yang diukur menggunakan Indeks Sharpe dan Treynor menunjukkan hasil yang berbeda.

Pada pengukuran kinerja Sharpe saham Indofarma Tbk menempati peringkat pertama selama awal tahun 2016. Sedangkan dalam pengukuran kinerja Treynor peringkat pertama dicapai oleh saham Kimia Farma Tbk. Nilai yang lebih tepat mestinya adalah pengukur Sharpe yang mengukur resiko sebagai resiko total yang sebenarnya terjadi. Sedangkan pengukur Treynor mengasumsikan 
portofolionya sebagai portofolio optimal yang kenyataannya tidaklah demikian. Pengukur Sharpe dan Treynor dapat dibandingkan untuk mengetahui tingkat optimalitas dari portofolio-portofolio yang dinilai kinerjanya. Jika kedua pengukur tersebut memberikan urutan hasil yang sama, maka portofolio-portofolio tersebut adalah portofolio optimal. Kenyataannya, pada penelitian ini hasil yang ditunjukkan oleh kedua pengukur tersebut tidaklah sama. Yang artinya sahamsaham yang diteliti bukan merupakan portofolio yang optimal. 


\section{BIBLIOGRAFI}

Andranik, 2012, Analisis Faktor-Faktor Yang Mempengaruhi Resiko Investasi Saham Pada Perusahaan Farmasi Yang Go Public Di Bursa Efek Indonesia, Denpasar, Universitas Warmadewa.

Darmadji, Tjiptono dan Hendy M. Fakhruddin, Pasar Modal Di Indonesia: Pendekatan Tanya Jawab, Jakarta, Salemba Empat.

Gadis, Febby Adinda Kurnia. 2014, Analisis Portofolio Model Indeks Tunggal Untuk Memilih Saham Optimal Pada Perusahaan Farmasi, Vol.6 No.5.

Graham, Benjamin. 2006, The Intelegent Invetor: Ajaran-Ajaran Inti dalam Berinvestasi, New York, HarperCollins.

Irkhami, Nafis. Analisis Resik Dalam Investasi Islam, Sekolah Tinggi Agama Islam Negeri Salatiga.

Jogiyanto, 2010, Teori Pasar Modal dan Portofolio, Yogyakarta, BPFE.

Kurniawan, Riski Dwi dan Nadia Asandimitra, 2014, Analisis Perbandingan Kinerja Indeks Saham Syariah dan Kinerja Indeks Saham Konvensional, Vol.2 No.4.

Martalena dan Maya Malinda. 2011, Pengantar Pasar Modal, Yogyakarta, ANDI.

Masyhuri dan Zainuddin, 2011, Metodologi Penelitian: Pendekatan Praktis dan Aplikatif, Bandung, Refika Aditama.

Rizkie Hizada, 2012, Analisis Kinerja Keuangan Perusahaan Farmasi: Studi Pada Perusahaan Farmasi di Bursa Efek Indonesia, Vol.1 No.2

Rusdin, 2008, Pasar Modal: Teori, Masalah, dan Kebijakan Dalam Praktik, Bandung, Alfabeta.

Sudarsono, Heri. 2003, Bank dan Lembaga Keuangan Syariah, Yogyakarta, EKONISIA.

Sugiyono. 2010, Metode Penelitian Bisnis, Bandung, Alfabeta

Sukamulja, Sukmawati. 2017, Pengantar Pemodelan Keuangan dan Analisis Pasar Modal, Yogyakarta, ANDI.

Triharnoto. 2009, The Doctor: Catatan Hati Seorang Dokter, Yogyakarta, Pustaka Anggrek.

Trisna, Steffany Yuadita. 2014, Skripi, Pengaruh Return On Assets (Roa), Return On Equity (Roe)Dan Net Profit Margin (Npm) Terhadap Harga Sahamperusahaan Food \& Beverages Periode 2009-2012di Bursa Efek Indonesia, Jawa Timur, Universitas Pembangunan Nasional "Veteran. 
Yulianrti, Ricke. 2013, Skripsi, Analisis Komparatif Kinerja Reksadana Saham Konvensional Dan Reksadana Saham Syariah Dengan Menggunakan Metode Sharpe, Treynor Dan Jensen Pada Bursa Efek Indonesia Periode Tahun 20102012, Semarang, Universitas Diponegoro.

Zulfikar. 2016, Pengantar Pasar Modal Dengan Pendekatan Statistika, Yogyakarta, Depublish 